\title{
Ligands of the peroxisome proliferator-activated receptor $\gamma$ inhibit hepatoce llular carcinoma cell proliferation
}

\author{
ZHE JIN, BAOXING JIA, YU FU, LUDONG TAN, QINGMIN CHEN, PEIQIANG JIANG and YAHUI LIU \\ Department of Hepatobiliary and Pancreatic Surgery, The First Hospital of \\ Jilin University, Changchun, Jilin 130021, P.R. China
}

Received March 17, 2017; Accepted July 5, 2017

DOI: $10.3892 / \mathrm{ol} .2017 .6731$

\begin{abstract}
This study was designed to investigate the regulatory role of the peroxisome proliferator-activated receptor $\gamma$ (PPAR $\gamma$ ) in the growth of hepatocellular carcinoma cells under the hypothesis that the levels of the phosphatase and tensin homologue deleted on chromosome 10 (PTEN) mRNA and the phosphorylated Akt (pAkt) protein would be affected by the presence of different receptor ligand concentrations. SMMC-7721 hepatocellular carcinoma cells were cultured in the presence of different concentrations of either 15-deoxyprostaglandin $\mathrm{J} 2$ (15-d-PGJ2) or pioglitazone and experiments were conducted in order to determine cell growth changes and measure levels of PTEN mRNA and pAkt protein. Our results after treatment with MTT showed the addition of ligands to the cultured cells inhibited their proliferation in a time- and dose-dependent manner. Also, flow cytometry after PI treatment showed the presence of ligands in the growth media could increase the proportion of G0/G1 phase cells, and decrease the proportion of S phase cells. Finally, the same cells exhibited increased levels of the PTEN mRNA by RT-PCR and pAkt protein by western blot analysis. Taken together, our results support the notion that PPAR $\gamma$ ligands can inhibit the proliferation of hepatocellular carcinoma cells in a time- and dose-dependent manner, and that this is at least in part due to the resulting upregulation of PTEN expression.
\end{abstract}

\section{Introduction}

Peroxisome proliferator-activated receptors (PPARs) are a class of ligand-dependent sequence-specific nuclear transcription factors that can be divided into three subtypes: PPAR $\alpha$, PPAR $\beta$ (PPARס) and PPAR $\gamma$. PPAR $\gamma$ has complex biological

Correspondence to: Dr Yahui Liu, Department of Hepatobiliary and Pancreatic Surgery, The First Hospital of Jilin University, 71 Xinmin Street, Changchun, Jilin 130021, P.R. China E-mail: yahuiliu12@126.com

Key words: peroxisome proliferator-activated receptor $\gamma$, hepatocellular carcinoma, PTEN, 15-deoxyprostaglandin J2, pioglitazone, pAkt functions and is involved in fat and glucose metabolism, monocyte activation and the inflammatory response; moreover, recent studies have found that it can also regulate tumor cell differentiation and inhibit tumor cell proliferation, features that can play roles in the development of gastrointestinal tumors (1-5). The human PPAR $\gamma$ gene is located in the P25 region of chromosome 3 and spans more than $100 \mathrm{~kb}$. Each species of PPAR $\gamma$ protein is highly conserved, and the amino acid sequences of PPAR $\gamma$ protein in human and mice share a 95\% homology (3). The post-transcriptional regulatory effect of PPAR $\gamma$ depends on its binding to ligands, but the exact range of endogenous ligands remain unidentified (4). There are two classes of PPAR $\gamma$ ligands known to exist currently, natural and synthetic ligands. 15-Deoxyprostaglandin J2 (15-d-PGJ2) and pioglitazone are the representatives of the two classes, respectively (5). After ligand binding in the nuclear membrane, heterodimers are formed with retinoic acid receptors, and those dimers bind to the peroxisome proliferator or responsive element in target gene promoter regions to activate their transcription (6). Phosphatase and tensin homologue deleted on chromosome 10 (PTEN) is a recently discovered tumor suppressor gene whose cognate protein can act as both lipid and protein phosphatase (7). A large number of studies have shown that PPAR $\gamma$ ligands can induce cell apoptosis, thereby inhibiting the growth of cancer cells (1-3). The activation of PPAR $\gamma$ can inhibit the proliferation of pancreatic, breast and colorectal cancers, by upregulating the expression of PTEN (8-10). We hypothesized that a PTEN ligand able to stimulate PPAR $\gamma$ could inhibit proliferation in hepatocellular carcinoma cells. In this study, the effect of PPAR $\gamma$ ligands on the growth of hepatocellular carcinoma cells and the changes in PTEN expression during the process were observed in vitro, in order to help elucidate a possible mechanism of PPAR $\gamma$ activation regulating the liver cancer growth.

\section{Materials and methods}

Cell culture. SMMC-7721 hepatocellular carcinoma cells (Shanghai Cell Institute of Chinese Academy of Sciences) were grown adhering to the walls of flasks, using RPMI-1640 culture solution (Gibco, Carlsbad, CA, USA) containing 10\% newborn calf serum (Lanzhou Minhai Biology, Gansu, China), $100 \mathrm{U} / \mathrm{ml}$ penicillin and $100 \mu \mathrm{g} / \mathrm{ml}$ streptomycin in an incubator containing $95 \% \mathrm{O}_{2}$ and $5 \% \mathrm{CO}_{2}$ at $37^{\circ} \mathrm{C}$. 
Determination of cell viability via MTT assay. MTT was prepared by dissolving $50 \mathrm{mg}$ MTT powder (Amresco LLC, Solon, OH, USA) in $10 \mathrm{ml}$ phosphate-buffered saline (PBS) and stirring with a magnet for $30 \mathrm{~min}$, followed with filtration with a $0.22-\mu \mathrm{m}$ microporous membrane for sterilization. The sterile solution was stored at $4^{\circ} \mathrm{C}$. SMMC-7721 cells in logarithmic growth phase were inoculated into 96 -well plates at $5 \times 10^{3}$ cells/well and incubated for $24 \mathrm{~h}$. Four groups were set up for $15-\mathrm{d}-\mathrm{PGJ} 2$ and pioglitazone treatments, a control group with $0 \mu \mathrm{mol} / 1$ of added drug, one with $10 \mu \mathrm{mol} / 1$, one with $25 \mu \mathrm{mol} / 1$, and another with $50 \mu \mathrm{mol} / 1$. 15-d-PGJ2 and pioglitazone were both purchased from Cayman Chemical, Inc. (Ann Arbor, MI, USA) and prepared with dimethyl sulfoxide (DMSO) into a storage concentration of $50 \mathrm{mmol} / \mathrm{l}$. The final concentration of DMSO in cell culture medium was not more than $0.1 \%$. The drugs were added to the wells after cells grew adhering to the wall. A blank control group was set up for zero setting. The cells were incubated in a $\mathrm{CO}_{2}$ incubator at $37^{\circ} \mathrm{C}$ for 24,48 and $72 \mathrm{~h}$ after being treated with either drug, then $100 \mu \mathrm{g}$ MTT were added to each well before and cells were incubated for another $4 \mathrm{~h}$. Then the media were discarded, and the cells were washed with PBS. Finally, $150 \mu 1$ DMSO were added. The cells were placed on a vibrating platform for $10 \mathrm{~min}$, and the $\mathrm{A}_{490}$ values were measured with a Model 680 microplate reader (Bio-Rad Laboratories, Inc., Hercules, CA, USA). The cell viability was calculated from the equation: Cell viability $=\left(\mathrm{A}_{490}\right.$ value in experimental group $/ \mathrm{A}_{490}$ value in control group) $\mathrm{x} 100 \%$.

Determination of cell cycle via flow cytometer. SMMC-7721 cells were seeded in $10-\mathrm{cm}$ culture dishes and the media was changed after culture for $24 \mathrm{~h}$. Fresh medium containing $50 \mu \mathrm{mol} / 1$ 15-d-PGJ2 or pioglitazone was added to each dish; cells were incubated for a further $72 \mathrm{~h}$ and then washed using PBS. Propidium iodide (PI) was used for staining the DNA inside the cells. The cell cycle analysis, giving the proportion of cells on each phase, was determined by flow cytometry (Bio-Rad Laboratories, Inc.).

Detection of levels of PTEN mRNA expression in cells via reverse transcription-polymerase chain reaction (RT-PCR). RNA extraction. After SMMC-7721 treatment of cells in culture with 0,25 and $50 \mu \mathrm{mol} / 1$ of either $15-\mathrm{d}-\mathrm{PGJ} 2$ or pioglitazone for $72 \mathrm{~h}$, the total RNA was extracted by Tri-Blue reagent (Shenneng Bocai, Shanghai, China) using the one-step method. Briefly, the old culture solution was discarded, and cells were washed twice with pre-cooled PBS. Cell pellets in $1.5 \mathrm{ml}$ Eppendorf tubes were mixed with $1 \mathrm{ml}$ Tri-Blue. Next, $200 \mu \mathrm{l}$ chloroform was added to each tube, and each tube mixed well in a vortex for $30 \mathrm{sec}$. After the centrifugation, the supernatant was retained and isopycnic isopropanol was added, followed by centrifugal removal of the supernatant. Cells were finally washed twice using alcohol, followed by drying at room temperature and addition of DEPC water.

$R T$. Total RNA was used for reverse transcription using MMLV reverse transcriptase. Briefly, $1 \mu 1$ total RNA, $1 \mu 1$ Oligo(dT) 18-Primer $(0.5 \mu \mathrm{g} / \mu \mathrm{l})$ and $10 \mu \mathrm{l}$ DEPC-treated $\mathrm{H}_{2} \mathrm{O}$ were all mixed together uniformly. A low speed centrifugation step was carried out before incubation at $70^{\circ} \mathrm{C}$ for $5 \mathrm{~min}$ to denature secondary structures. Then the samples were placed on ice, and the reactions were prepared by adding $4 \mu 15 \mathrm{X}$ reaction buffer and $1 \mu \mathrm{l} \mathrm{R} 1$ bolock ribonuclease inhibitor; then $1 \mu 110 \mathrm{nM}$ dNTP mix. The tubes were briefly centrifuged, and then incubated at $37^{\circ} \mathrm{C}$ for $5 \mathrm{~min}$. Next, $1 \mu \mathrm{l}$ RevertAid MuLV Reverse Transcriptase was added, mixed and incubated for further $60 \mathrm{~min}$. The reactions were stopped at $70^{\circ} \mathrm{C}$; and the tubes were placed on ice. The equivalent cDNA obtained was amplified by PCR to detect PTEN mRNA levels with amplified $\beta$-actin as the internal reference product. All steps were repeated at least 3 times for each experimental group.

PCR. PTEN primers were synthesized by Shenneng Bocai. PTEN: Upstream primer, 5'-AGACCATAACCCACC ACAGC-3' and downstream primer, 5'-ACCAGTTCGTCCC TTTCCAG-3'; amplified fragment length, 123 bp. $\beta$-actin: Upstream primer, 5'-AGCGGGAAATCGTGCGTG-3' and downstream primer, 5'-CAGGGTACATGGTGGTGCC-3'; amplified fragment length, $287 \mathrm{bp}$. According to the instructions, PTEN primers were dissolved into $10 \mu \mathrm{mol} / 1$ working solution using DEPC- $\mathrm{H}_{2} \mathrm{O}$ to prepare $50 \mu \mathrm{l}$ PCR reactions. The reactions were placed in a thermocycler instrument (Bio-Rad Laboratories, Inc.). The protocol for PTEN amplification was set up with an initial denaturation at $94^{\circ} \mathrm{C}$ for $4 \mathrm{~min}$, followed by 35 cycles of denaturation at $94^{\circ} \mathrm{C}$ for $20 \mathrm{sec}$, annealing at $60^{\circ} \mathrm{C}$ for $20 \mathrm{sec}$, and extension at $72^{\circ} \mathrm{C}$ for $40 \mathrm{sec}$; and a final extension at $72^{\circ} \mathrm{C}$ for $10 \mathrm{~min}$. For $\beta$-actin amplification the protocol included an initial denaturation at $94^{\circ} \mathrm{C}$ for $3 \mathrm{~min}$, followed by 35 cycles of denaturation at $94^{\circ} \mathrm{C}$ for $30 \mathrm{sec}$, annealing at $60^{\circ} \mathrm{C}$ for $45 \mathrm{sec}$, and extension at $72^{\circ} \mathrm{C}$ for $1 \mathrm{~min}$, with a final extension at $72^{\circ} \mathrm{C}$ for $10 \mathrm{~min}$. The PCR products were stored at $4^{\circ} \mathrm{C}$. Finally, agarose gel electrophoresis was performed to analyze the results.

Detection of the expression of PTEN and pAkt protein via western blot analysis. SMMC-7721 cells were inoculated into 6-well plates and cultured for $24 \mathrm{~h}$ under normal conditions. Once the cells adhered to the walls, the medium was changed. The cells were next incubated with $0,10,25$ and $50 \mu \mathrm{mol} / 1$ of either 15-d-PGJ2 or pioglitazone for $72 \mathrm{~h}$. After washing cells twice with PBS, $150 \mu \mathrm{l}$ cell lysis buffer [20 mmol/1 Tris (pH 7.5), 4 mmol/1 EDTA (pH 8.0), 2\% SDS] were added to each well to crack open the cell membranes via a cell sonicator (JY96-II; Ningbo Xinzhi Biologic Science and Technology Co., Ltd., Ningbo, China). After a 10,500 x g centrifugation step for $10 \mathrm{~min}$, the supernatants containing the soluble protein fractions were transferred into pre-cooled EP tubes. Protein concentrations were determined by the BCA method. Next, $20 \mu \mathrm{g}$ total protein were added to loading buffer at a ratio of 4:1, and boiled for $5 \mathrm{~min}$; after the protein denaturation, the samples were loaded onto a gel for electrophoresis and then transferred onto a PVDF membrane (Roche Diagnostics, Basel, Switzerland). Standard western blot protocols were followed (protein blotting system; Bio-Rad Laboratories, Inc.). Mouse monoclonal PTEN antibody (dilution, 1:1,000, catalog no. ab79156) or mouse monoclonal pAkt (dilution, 1:1,000, catalog no. ab105731), purchased from Abcam (Cambridge, MA, USA) were incubated with the membranes overnight at $4^{\circ} \mathrm{C}$. TBP was used for membrane washing. Then, HRP-labeled goat anti-mouse secondary antibody (dilution, 1:5,000; catalog no. ab6785; Abcam, Cambridge, MA, USA) was added and incubated at room temperature 
Table I. Effects of 15-d-PGJ2 and pioglitazone on the proliferation of SMMC-7721 cells (mean \pm SD).

\begin{tabular}{|c|c|c|c|c|}
\hline Groups & $\begin{array}{l}\text { Drug concentration } \\
\qquad(\mu \mathrm{mol} / 1)\end{array}$ & $24 \mathrm{~h}$ & $48 \mathrm{~h}$ & $72 \mathrm{~h}$ \\
\hline \multirow[t]{3}{*}{ 15-d-PGJ2 } & 10 & $87.61 \pm 1.73$ & $81.98 \pm 1.85$ & $77.86 \pm 2.21$ \\
\hline & 25 & $65.70 \pm 1.81$ & $61.83 \pm 1.72$ & $54.89 \pm 1.90$ \\
\hline & 50 & $48.52 \pm 1.82$ & $47.93 \pm 1.94$ & $30.79 \pm 2.51$ \\
\hline \multirow[t]{3}{*}{ Pioglitazone } & 10 & $93.56 \pm 2.25$ & $84.73 \pm 2.07$ & $82.04 \pm 2.19$ \\
\hline & 25 & $70.63 \pm 2.22$ & $63.67 \pm 1.55$ & $58.26 \pm 2.34$ \\
\hline & 50 & $54.43 \pm 1.84$ & $40.96 \pm 2.29$ & $33.79 \pm 2.93$ \\
\hline
\end{tabular}

15-d-PGJ2, 15-deoxyprostaglandin J2.

for $1 \mathrm{~h}$. TBST was used for washing the membrane three times for $5 \mathrm{~min}$. Finally, the ECL chemiluminescence method was used for visualizing the results. Additionally, an $\alpha$-tubulin antibody (dilution, 1:5,000; catalog no. 5335) was used as the internal reference. Mouse anti-human PTEN monoclonal antibody (dilution, 1:1,000; catalog no. 9556) and mouse anti-human pAkt monoclonal antibody (dilution, 1:1,000; catalog no. 12694) were purchased from Cell Signaling Technology, Inc. (Beverly, MA, USA). Peroxidase (HRP)-labeled goat anti-mouse secondary antibody (dilution, 1:5,000; catalog no. 4410) was purchased from Cell Signaling Technology, Inc. (Beverly, MA, USA).

Statistical analysis. The SPSS 12.0 statistical software (IBM, Armonk, NY, USA) was used for statistical analyses. All variables were presented as mean \pm standard deviation (mean $\pm \mathrm{SD}$ ); analysis of variance (ANOVA) and t-test were used for inter-group differences. $\mathrm{P}<0.05$ was considered to indicate a statistically significant difference.

\section{Results}

Effects of 15-d-PGJ2 and pioglitazone on proliferation of SMMC-7721 cells. SMMC-7721 cells were treated with different concentrations of $15-\mathrm{d}-\mathrm{PGJ} 2$ or pioglitazone. It was found that both of the PPAR $\gamma$ ligands had a significant inhibitory effect on the proliferation of SMMC-7721 cells. The inhibitory effects were more pronounced with increasing drug concentrations $(\mathrm{p}<0.05)$. Table I obtain details of time- and dose-dependence on cellular proliferation.

Cell cycle effects of 15-d-PGJ2 and pioglitazone on SMMC-7722 cell cycle. 15-d-PGJ2 and pioglitazone can inhibit the proliferation of SMMC-7721 cells, therefore we used PI and flow cytometry to further investigate the ligand effects on the cell cycle. The proportion of G0/G1 phase SMMC-7721 cells after treatment with $50 \mu \mathrm{mol} / 1$ 15-d-PGJ2 or pioglitazone for $72 \mathrm{~h}$ was significantly higher than the same proportion in cells without treatment $(\mathrm{p}<0.05)$. However, the proportion of $\mathrm{S}$ phase cells was significantly decreased $(\mathrm{p}<0.05)$, and the proportion of $\mathrm{G} 2 / \mathrm{M}$ phase cells was not increased significantly $(\mathrm{p}<0.05)$ in the high-dose treatment groups. This apparent inhibition at the level of replication can be seen in Table II.
Table II.Effects of 15-d-PGJ2 and pioglitazone on SMMC-7722 cell cycle (mean $\pm \mathrm{SD})$.

\begin{tabular}{lccc}
\hline & \multicolumn{3}{c}{ Cell cycle distribution $(\%)$} \\
\cline { 2 - 4 } Group & G0/G1 phase & S phase & G2/M phase \\
\hline Control & $63.45 \pm 1.49$ & $32.19 \pm 1.83$ & $4.36 \pm 0.64$ \\
$\begin{array}{l}15-\mathrm{d}-\mathrm{PGJ} 2 \\
(50 \mu \mathrm{mol} / \mathrm{l})\end{array}$ & $76.87 \pm 1.09$ & $18.28 \pm 1.46$ & $4.85 \pm 0.58$ \\
Pioglitazone & $78.31 \pm 1.28$ & $16.90 \pm 1.08$ & $4.79 \pm 0.73$ \\
$(50 \mu \mathrm{mol} / \mathrm{l})$ & & & \\
\hline
\end{tabular}

15-d-PGJ2, 15-deoxyprostaglandin J2.

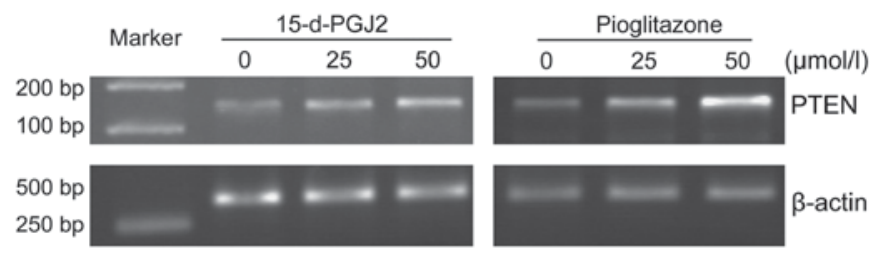

Figure 1. Agarose gel electrophoresis after RT-PCR showing the effects of 15-d-PGJ2 and pioglitazone on the expression of the PTEN mRNA in SMMC-7721 cells. Lane 1, 15-d-PGJ2 (0 $\mu \mathrm{mol} / 1)$; lane 2, 15-d-PGJZ (25 $\mu \mathrm{mol} / 1)$; lane 3, 15-d-PGJ2 (50 $\mu \mathrm{mol} / \mathrm{l})$; lane 4, pioglitazone ( $0 \mu \mathrm{mol} / 1)$; lane 5, pioglitazone $(25 \mu \mathrm{mol} / \mathrm{l})$; and lane 6 , pioglitazone $(50 \mu \mathrm{mol} / \mathrm{l})$. 15-d-PGJ2, 15-deoxyprostaglandin J2; PTEN, phosphatase and tensin homologue deleted on chromosome 10 .

Effects of 15-d-PGJ2 and pioglitazone on the expression levels of PTEN mRNA in SMMC-7721 cells. After treating SMMC-7721 cells with 15-d-PGJ2 or pioglitazone for $72 \mathrm{~h}$, it was found that the expression levels of PTEN mRNA were significantly increased in a drug concentration manner for both ligand treatments (Fig. 1).

Effects of 15-d-PGJ2 and pioglitazone on the expression levels of PTEN and pAkt protein in SMMC-7721 cells. After either 15-d-pGJ2 or pioglitazone treatment for $72 \mathrm{~h}$, the expression of PTEN protein in SMMC-7721 cells was increased in a drug concentration manner $(\mathrm{p}<0.05)$. At the same time, the 
A
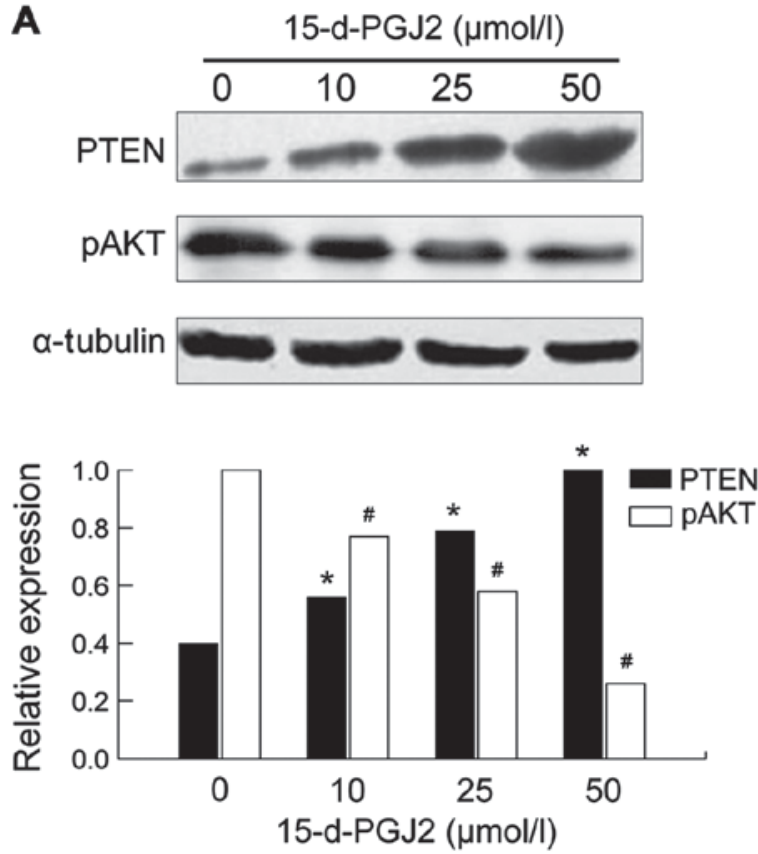

B
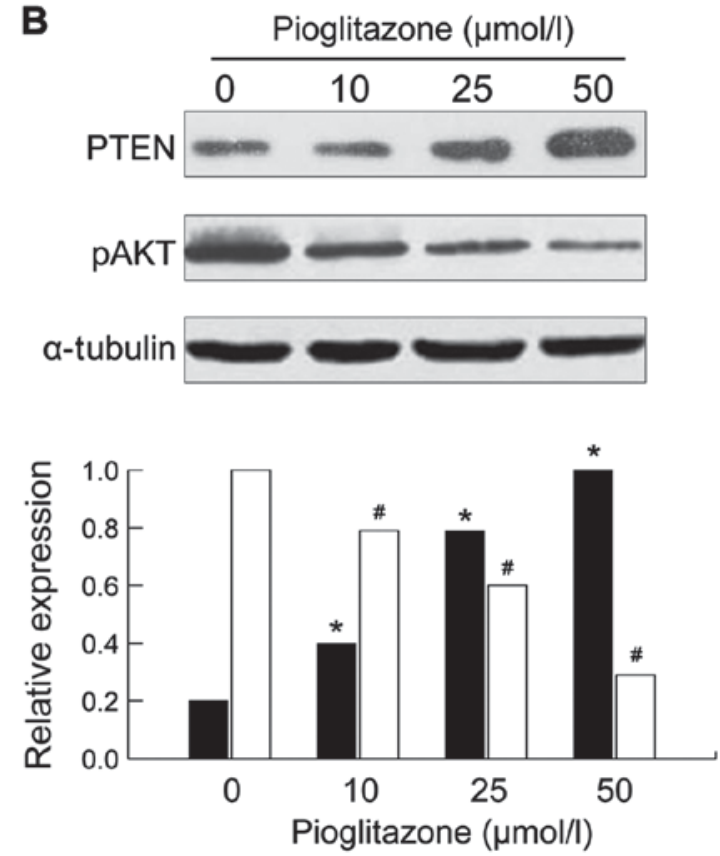

Figure 2. Effect of 15-d-PGJ2 and pioglitazone on the expressions of PTEN and pAkt protein in SMMC-7721 cells. (A) Western blot analysis showed the expression level of PTEN was increased successively after being treated with 10,25 and $50 \mu$ mol 15 -d-PGJ2, compared with that after being treated with $0 \mu \mathrm{mol} / 1$ 15-d-PGJ2 ("p<0.05); the expression level of pAkt was decreased successively ( $\left.{ }^{*} \mathrm{p}<0.01\right)$. (B) The expression level of PTEN was increased successively after being treated with 10,25 and $50 \mu \mathrm{mol}$ pioglitazone, compared with that after being treated with $0 \mu \mathrm{mol} / 1$ pioglitazone $\left({ }^{*} \mathrm{p}<0.05\right)$; the expression level of pAkt was decreased successively (\#p<0.01). 15-d-PGJ2, 15-deoxyprostaglandin J2; PTEN, phosphatase and tensin homologue deleted on chromosome 10.

expression of the protein of the downstream pAkt gene was decreased and the difference was more significant with higher amounts of drug concentration used ( $\mathrm{p}<0.05)$ (Fig. 2).

\section{Discussion}

PPAR $\gamma$ is a class of ligand-dependent sequence-specific nuclear transcription factors, and 15-d-PGJ2 and pioglitazone are its natural and synthetic ligands, respectively (11). The effects of 15-d-PGJ2 and pioglitazone on the growth of SMMC-7721 hepatocellular carcinoma cells under different concentrations and different treatment lengths were observed by MTT assay. The results showed that both drugs had a significant time- and dose-dependent inhibitory effect on the cell growth. Furthermore, an analysis of the relation between the inhibitory effect and the cell cycle performed by flow cytometry, found that 15 -d-PGJZ and pioglitazone can both significantly increase the proportion of G0/Gl phase cells and decrease the proportion of $\mathrm{S}$ phase cells. This suggests that the inhibitory effect is at least partially related to the inhibition of cell DNA synthesis and mitosis, which blocks the transition of cells from G1 to $\mathrm{S}$ phase.

The tumor suppressor function of PTEN has been attributed to its lipid phosphatase activity (12). PTEN can catalyze the dephosphorylation of phosphorylated phosphatidylphthalide 4,5-diphosphoinositol (PIP2) and phosphatidic acid 3,4,5-triphosphoinositol (PIP3) (13). Previous studies have shown that PTEN can specifically inhibit the activation of phosphatidylinositol-3-kinase-dependent protein kinase $\mathrm{B}$ (PKB or Akt), and PI3K catalyzes the phosphorylation of phosphoinositide on cell membranes to produce PIP2 and PIP3, the latter of which further activates the downstream
Akt (14). Therefore, PTEN can antagonize the activity of PIP3 and PIP2, and reduce their concentration in cells, thereby inhibiting the phosphorylation of Akt $(15,16)$. Inactivation of PTEN may promote cell proliferation and tumor angiogenesis, by inhibiting cell apoptosis (17-19).

It was found in this study that, after treatment with 15-d-pGJ2 or pioglitazone, SMMC-7721 cells increased the expression levels of their PTEN mRNA in a ligand concentration manner. Furthermore, western blot analysis found that the expression of the PTEN protein was also increased; and correspondingly, the expression of the downstream pAkt gene product (belonging to the PI3K pathway) was decreased more significantly with increasing ligand concentrations. Finally, the results of the MTT assay showed that the proliferation of SMMC-7721 cells was inhibited by the PPAR $\gamma$ ligands in a dose-dependent manner. Taken together, the above results suggest that the inhibitory effect of the PPAR $\gamma$ ligands, $15-\mathrm{d}-\mathrm{pGJ} 2$ or pioglitazone, on the proliferation of the hepatocellular carcinoma cells may be achieved by upregulating the expression of PTEN (a cancer suppressor gene), thus affecting the PI3K pathway and inhibiting the phosphorylation of Akt.

At the same time, there is evidence that PTEN can also act as a cell cycle regulator by stimulating P27 expression (8). P27 is an important cyclin kinase inhibitor that can inhibit the activity of G1 phase cyclin-dependent kinase (CDK) and induce the G1 phase cell arrest (9). The results of flow cytometry in our study showed that the proportion of G0/G1 phase cells was increased and that of S phase cells was decreased significantly after addition of PPAR $\gamma$ ligands. This suggests that PPAR $\gamma$ ligands inhibit the proliferation of SMMC-7721 by blocking the transition to $\mathrm{S}$ phase, and this could be due to 
upregulation of the expression of PTEN, leading to an increase in the p27 protein level, which would induce a G1 phase cell arrest.

In this study, two ligands of PPAR $\gamma, 15-d-P G J 2$ and pioglitazone, were used to confirm their inhibitory effect on the proliferation of SMMC-7721 hepatocellular carcinoma cells, and this inhibitory effect was related to the expression of PTEN, a tumor suppressor gene. In conclusion, we believe that PPAR $\gamma$ ligands may act as tumor suppressors, which categorizes them as potential clinical treatments against liver cancer.

\section{References}

1. Li M, Lee TW, Mok TS, Warner TD, Yim AP and Chen GG: Activation of peroxisome proliferator-activated receptor-gamma by troglitazone (TGZ) inhibits human lung cell growth. J Cell Biochem 96: 760-774, 2005.

2. Valentiner U, Carlsson M, Erttmann R, Hildebrandt $\mathrm{H}$ and Schumacher U: Ligands for the peroxisome proliferatoractivated receptor-gamma have inhibitory effects on growth of human neuroblastoma cells in vitro. Toxicology 213: $157-168,2005$

3. Fenner MH and Elstner E: Peroxisome proliferator-activated receptor-gamma ligands for the treatment of breast cancer. Expert Opin Investig Drugs 14: 557-568, 2005.

4. Lu J, Imamura K, Nomura S, Mafune K, Nakajima A, Kadowaki T, Kubota N, Terauchi Y, Ishii G, Ochiai A, et al: Chemopreventive effect of peroxisome proliferator-activated receptor gamma on gastric carcinogenesis in mice. Cancer Res 65: 4769-4774, 2005.

5. Toyoda M, Takagi H, Horiguchi N, Kakizaki S, Sato K, Takayama $\mathrm{H}$ and Mori $\mathrm{M}$ : A ligand for peroxisome proliferator activated receptor gamma inhibits cell growth and induces apoptosis in human liver cancer cells. Gut 50: 563-567, 2002

6. IJpenberg A, Jeannin E, Wahli W and Desvergne B: Polarity and specific sequence requirements of peroxisome proliferator-activated receptor (PPAR)/retinoid X receptor heterodimer binding to DNA. A functional analysis of the malic enzyme gene PPAR response element. J Biol Chem 272: 20108-20117, 1997.

7. Li J, Yen C, Liaw D, Podsypanina K, Bose S, Wang SI, Puc J, Miliaresis C, Rodgers L, McCombie R, et al: PTEN, a putative protein tyrosine phosphatase gene mutated in human brain, breast, and prostate cancer. Science 275: 1943-1947, 1997.
8. Chen WC, Lin MS and Bai X: Induction of apoptosis in colorectal cancer cells by peroxisome proliferators-activated receptor gamma activation up-regulating PTEN and inhibiting PI3K activity. Chin Med J (Engl) 118: 1477-1481, 2005.

9. Farrow B and Evers BM: Activation of PPARgamma increases PTEN expression in pancreatic cancer cells. Biochem Biophys Res Commun 301: 50-53, 2003.

10. Patel L, Pass I, Coxon P, Downes CP, Smith SA and Macphee CH: Tumor suppressor anti-inflammatory actions of PPAR gamma agonists are mediated up-regulation of PTEN. Curr Biol 11: 764-768, 2001.

11. Okano H, Shiraki K, Inoue H, Yamanaka T, Deguchi M, Sugimoto K, Sakai T, Ohmori S, Fujikawa K, Murata K, et al: Peroxisome proliferator-activated receptor gamma augments tumor necrosis factor family-induced apoptosis in hepatocellular carcinoma. Anticancer Drugs 13: 59-65, 2002.

12. Motomura W, Takahashi N, Nagamine M, Sawamukai M, Tanno S, Kohgo Y and Okumura T: Growth arrest by troglitazone is mediated by $\mathrm{p} 27^{\mathrm{Kip1}}$ accumulation, which results from dual inhibition of proteasome activity and Skp2 expression in human hepatocellular carcinoma cells. Int J Cancer 108: 41-46, 2004.

13. Ma H, Sprecher HW and Kolattukudy PE: Estrogen-induced production of a peroxisome proliferator-activated receptor (PPAR) ligand in a PPARgamma-expressing tissue. J Biol Chem 273: 30131-30138, 1998.

14. Han B, Dong Z, Liu Y, Chen Q, Hashimoto K and Zhang JT: Regulation of constitutive expression of mouse PTEN by the 5'-untranslated region. Oncogene 22: 5325-5337, 2003.

15. Cantley LC and Neel BG: New insights into tumor suppression PTEN suppresses tumor formation by restraining the phosphoinositide 3-kinase/AKT pathway. Proc Natl Acad Sci USA 96: 4240-4245, 1999.

16. Leslie NR and Downes CP: PTEN: The down side of PI 3-kinase signalling. Cell Signal 14: 285-295, 2002.

17. Stambolic V, Suzuki A, de la Pompa JL, Brothers GM, Mirtsos C, Sasaki T, Ruland J, Penninger JM, Siderovski DP and Mak TW: Negative regulation of PKB/Akt-dependent cell survival by the tumor suppressor PTEN. Cell 95: 29-39, 1998.

18. Zhong H, Chiles K, Feldser D, Laughner E, Hanrahan C, Georgescu MM, Simons JW and Semenza GL: Modulation of hypoxia-inducible factor 1alpha expression by the epidermal growth factor/phosphatidylinositol 3-kinase/PTEN/AKT/FRAP pathway in human prostate cancer cells: Implications for tumor angiogenesis and therapeutics. Cancer Res 60: 1541-1545, 2000.

19. Lu Y, Lin YZ, LaPushin R, Cuevas B, Fang X, Yu SX, Davies MA, Khan H, Furui T, Mao M, et al: The PTEN/MMAC1/TEP tumor suppressor gene decreases cell growth and induces apoptosis and anoikis in breast cancer cells. Oncogene 18: 7034-7045, 1999. 